\title{
Contribution Of Principals To Food Safety In Public Secondary Schools In Kakamega County, Kenya
}

\author{
Pamela Ananda*, Prof. Enose M.W.Simatwa*, Dr. Stella Juma** \\ *Faculty of Education, Tom Mboya University, \\ **Faculty of Education, Rongo University. \\ DOI: 10.29322/IJSRP.12.01.2022.p12162 \\ http://dx.doi.org/10.29322/IJSRP.12.01.2022.p12162
}

\begin{abstract}
Safety of students in schools is a matter of concern globally. In Kenya, students have lost their lives in the past four years due to arson, accidents, and food poisoning in spite of existence of Safety Standards Manual for schools of 2008. In Kakamega County Secondary Schools, there have been 65 deaths, 205 cases of food poisoning, 112 gang rape, 103 floods, 107 landslides, 50 fires, 102 lightening, 15 cyclones and 10 accidents in school buses from the year 2012 - 2016. Principals have a responsibility of ensuring safety of students in schools. The desire of this study therefore was to establish the contribution of principals to food safety in public secondary schools in Kakamega County. The objective of this study was to establish the contribution of principals to food safety in public secondary schools. The conceptual framework showing interrelationships between contribution of principals and disaster management preparedness was used to guide the study. Study population was 419 principals and 1 County Quality Assurance and Standards Officer. The sample size of 200 principals and 1 CQASO was used in the study. The study established that there was a positive relationship between contribution of principals to school disaster management preparedness and food safety in public secondary schools in Kakamega. The findings of the study revealed that secondary schools in Kakamega County are faced with a variety of disasters with varying magnitude as signified by coefficient 0.663 at a significant level of 0.05 . The study concluded that principals contribution enhanced disaster management preparedness in secondary schools in Kakamega County. The study recommended that principals should make an effort in ensuring school have adequate safe storage facility for food items, illegal hawking/vending of food in school compound is prohibited, food purchased for students is in good condition, fresh and safe, areas where food is prepared is clean, all food sellers in school have medical certificates, students observe basic hygiene before and after meals and learners with special needs are catered for in relation to their dietary needs. The study recommended that principals should know the importance of students consuming safe food for promotion of their health and for effective learning in schools in Kakamega County.
\end{abstract}

Index Terms- Safety, Storage, Hawking, Hygiene, Dietary needs, Health certificate

\section{INTRODUCTION}

$\mathrm{D}$ isaster is a disruption of the functioning of a school causing widespread losses that exceed the ability of the affected students in public secondary schools to cope with using its own resources.

Safety of students in schools is very important, the threats to safety include disasters, such as landslides, earth tremors, floods, fires, accidents and droughts, according to United Nations Disaster Programme. Republic of Kenya, (2008) states food safety is access and consumption of wholesome food that promotes good health and optimal body functioning. Ooro (2008) in his research has shown that, learners who have access to wholesome food have more enjoyable and successful learning experience. Knowledge and adequately trained foodservice staff can prevent food borne illness outbreaks originating in the cafeteria (FSP, 2005). Shaw (2002) in a study on international experiences and actions in promoting school safety states that new collections of exemplary, good or promising practices have been published

Maritim (2014) in her study on school safety and emergency preparedness: an assessment of public boarding secondary schools in Nandi North District used a population that was only given as 17 schools all the students and all the teachers. Okumu (2014), in her study on perceptions on opportunities and challenges for public secondary school principals in the implementation of selected safety policy guidelines in Kisumu West District, Kenya concluded that there are challenges hampering implementation of the safety guidelines. Okumu (2014) study findings were that principals had great opportunities to implement school community relations, health, hygiene guidelines, less opportunity to implement transport safety and food safety. Ngecu and Mathu (1999), study in Kenya established that, heavy rainfall resulted in floods and landslides in various parts of the country as well as loss of lives. Oriang (2001) in his study in Hawinga Girls secondary school established that, the school had no perimeter fencing making it easier for the gangsters to access the school and rape students. Gicheru (1998) states that overcrowding was one of the factors that contributed to the death of 27 girls in the 1998 Bombolulu Girls dormitory fire. Odalo (2001) stated that the absence of firefighting equipment and emergency exits led to the high death toll during the Kyanguli Secondary School fire. 


\section{RESEARCH OBJECTIVE}

The research objective was to establish the contribution of principals to food safety in public secondary schools.

\section{Synthesis of literature on contribution of principals to food safety in public secondary schools.}

Republic of China (2011), states more than 300 students at Changzhou City got food poisoning after lunch and it was established this was due to unsanitary conditions at school. Park, Kwak and Chang (2010), in their study on evaluation of food safety training for food handlers operations in Korea, 510 food borne disease outbreaks with 9,686 patients were reported with 93 of them being attributed to institutional food service operations. Food safety evaluation in Ziaria, Nigeria using the Hazard Analysis Critical Control Plan (HACCP) system, found out that water for drinking and cooking was from dirty tap water environments, uncovered wells and boreholes Oranusi et, al (2007). Republic of Kenya, (2008) states food safety is access and consumption of wholesome food that promotes good health and optimal body functioning. Ooro (2008) in his research has shown that, learners who have access to wholesome food have more enjoyable and successful learning experience. Knowledge and adequately trained foodservice staff can prevent food borne illness outbreaks originating in the cafeteria (FSP,2005).

Poor food handling and unsanitary conditions practices lead to high rates of food contamination and outbreak of food borne diseases, sanitation starts with physical facilities and environment of a food plant (USFDA, 2008). FAO/WHO, (2005), asserts that, factors' leading to food poisoning of students in school is due to buying food from food vendors, foods are subjected to repeated contaminations from unwashed hands and the wrapping materials and some vendors in Accia, Harare Lilongwe and Lusaka wash their hands in one bucket used for washing utensils which leads to contamination. In literature such as the UNESCO (2007) and (ISDR) report (2008), Fothergill and Peek (2004), Paton and Johnston (2001) and Hosseini and lzadkhah (2006) there is strong evidence that the more prepared and knowledgeable a community is, the more resilient it becomes to disaster. Shaw et al., (2004), Hosseini and Izadkhah (2006) and Ozmen (2006) maintain that school education is important to ensure that learners respond appropriately.

Park, Kwak and Changi (2010) on evaluation of food safety training for food handlers in restaurant operations found out that in Korea, 510 food borne disease outbreaks with 9,686 patients were reported with 93 of them attributed to service operations. World Food Program (2014) states a daily school meal provides a strong initiative to send children to school and keep them which allows them to focus on their studies rather than their stomachs. Lunch programs have favourable effects on educational attainment, Musamali (2008) regards school feeding program as one which improves school enrollment and attendance, academic performance and nutritional status of school children. Oranusi et al (2007) on food evaluation in schools in Ziara, Nigeria found out that, drinking water and for cooking was from dirty tap water, uncovered wells and boreholes. Water was stored in dirty tanks not regularly cleaned. Blink (2001) shows there was a study on established state of food safety implementation. Pandhal (2005) in his study in Harare in Zimbabwe determined oral health status among secondary school students concluded that, students lacked knowledge regarding preventive measures towards good oral health.

Muigai (2011) conducted a study in Kenya to establish the level of implementation of safety standards guidelines in public secondary schools in Ngong Division, Kajiado District. The study established that knowledge of the most safety guidelines among the institutional head teachers, teachers and students was poor. It was recommended that school managers should beef up security by employing an adequate number of watchmen (Savula \& Atsiaya, 2004), this will help in ensuring no authorized food vendors get access to school compound. Musamali (2008), focused on school feeding program, World Food Program (2014) focused on medical food handlers.. Savula \& Atsiaya, (2004), established that principals to ensure no authorized food vendors get access to school compound. Musamali (2008), focused on school feeding program, World Food Program (2014) focused on medical food handlers.

\section{CONCEPTUAL FRAMEWORK}

This study was guided by conceptual framework which helps to give a clearer understanding of relationship of the variables. The conceptual framework in Figure 1, postulates that disaster management in schools depends on principals contribution. 


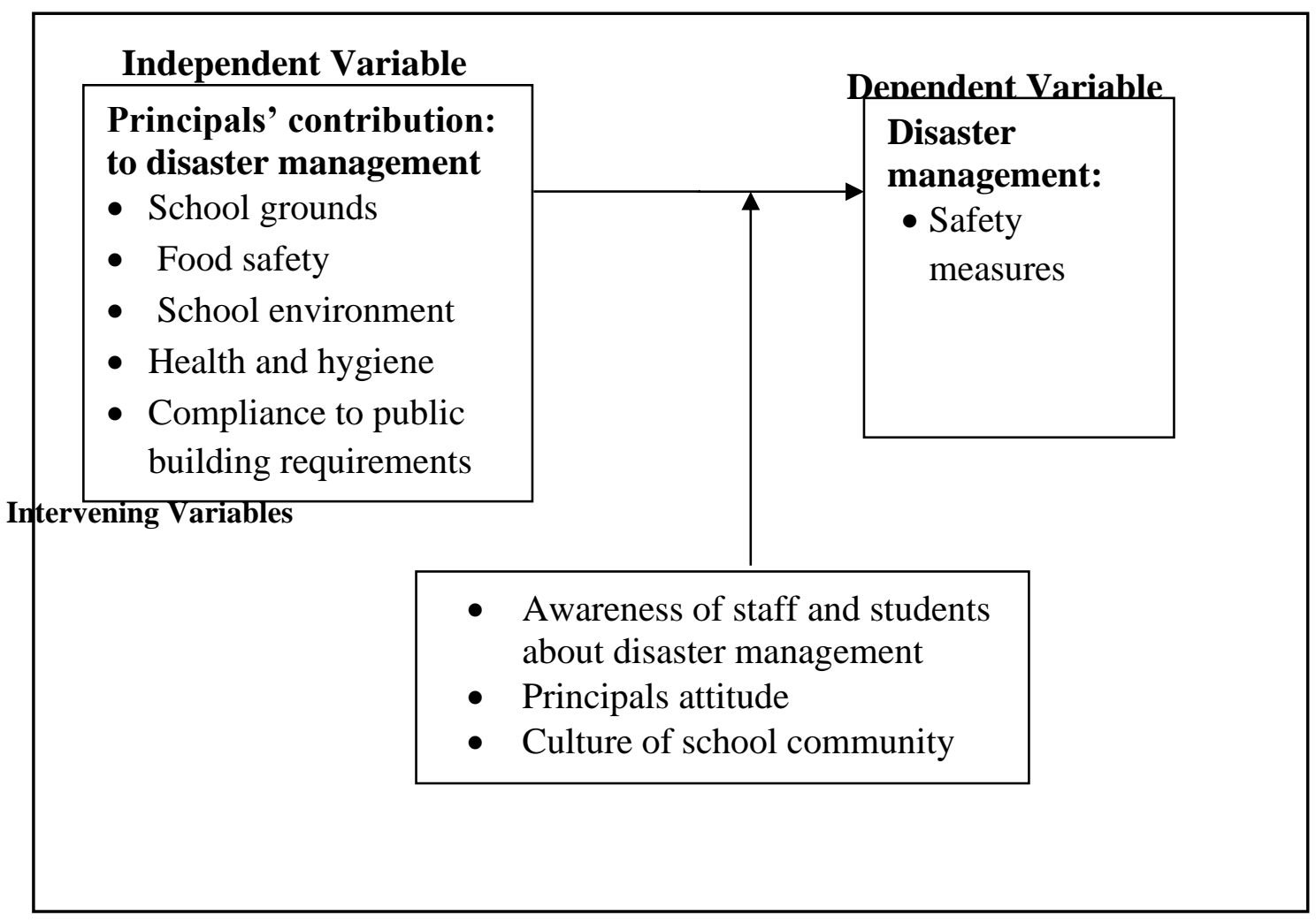

Figure 1: A Conceptual Framework Showing Contribution of Principals to food safety in Public Secondary Schools in Kakamega County Source: Researcher

The Conceptual framework shows relationship between independent variable and dependent variable. Intervening variables play a mediating role on the influence of independent variable on the dependent variable (Mugenda \& Mugenda, 2003) and they moderate their influences and are controlled through assumptions.

\section{RESEARCH METHODOLOGY}

The research design for this study was a correlational research design. The study targeted 419 principals in secondary schools in the County. The sample sizes were 200 principals and 1 County Quality Assurance and Standards Officer determined by Fishers' fomula. The study used multi stage sampling since the population involved had divergent characteristics, Saturated sampling technique was used to select CQASO. Questionnaires, interview schedule and observation checklist were used to collect data. Face and content validity of questionnaires were determined by experts in educational policy and management. Reliability of questionnaires were determined through pilot study in $10 \%$ of the schools using test-retest technique Pearson's ' $r$ ' coefficients for principals contribution questionnaire was 0.81 and 0.88 respectively at a set P-value of 0.05 , meaning they were reliable. Quantitative data from closed-ended items in questionnaires was analyzed after being coded per objective and per item and aspect. A rating scale was prepared with a coding of 1 to 5 which was later interpreted using correlational research analysis and presented on tables showing the Model Summary, ANOVA and Coefficients. Regression analysis was computed to determine contribution of principals and ANOVA was used to test if the overall study model was significant. Qualitative data were transcribed, analyzed and reported in emergent themes and sub-themes.

\section{RESULTS: RESEARCH QUESTION}

The research question responded to was: What are contributions of principals to food safety in public secondary schools? The response to this question by principals was shown in Table 1. A correlation research describing existing relationship between contribution of principals and disaster management preparedness was used to give the degree to which they are related by use of a correlation coefficient. The design was used to determine whether or not and to what extent an association exists between the two or more indicators. Data was collected on the principals contributions to: adequate storage facility for food items, prohibition on illegal hawking or vending of food in school, food purchased for students, ensure food areas are clean, ensuring all food sellers in school have medical certificates, basic hygiene before and after meals and dietary needs of students. 
Table 1: Principals Ratings on Their Contributions to School Disaster Management Preparedness on Food Safety

\begin{tabular}{lll}
\hline Mean Ratings & Frequency $(\mathbf{F})$ & Percentage $\mathbf{( \% )}$ \\
\hline $1.00-1.44$ & 0 & 0 \\
$1.45-244$ & 0 & 0 \\
$2.45-3.44$ & 43 & 23.88 \\
$3.45-4.44$ & 135 & 75 \\
$4.45-5.00$ & 2 & 1.11 \\
Total & $\mathbf{1 8 0}$ & $\mathbf{1 0 0}$ \\
\hline
\end{tabular}

Source: Field Data, 2018 -2019

Interpretation:

$1.00-1.44$ Very Low (VL)

$1.45-2.44$ Low (L)

$2.45-3.44$ Moderate $(\mathrm{M})$

$3.45-4.44$ High $(\mathrm{H})$

$4.45-5.00$ Very High (VH)

Table 1 indicates that 135(75\%)schools the level of disaster management preparedness was high while in $43(23.88 \%)$ schools the preparation was moderate. In $2(1.11 \%)$ schools preparation was very high, there was everything in place and the students were very secure as regards food safety.

Table 2: Status of Food Safety

\begin{tabular}{lll}
\hline Mean Ratings & Frequency $\mathbf{f}$ & Percentage $\%$ \\
\hline $1.00-1.44$ & 0 & 0 \\
$1.45-244$ & 0 & 0 \\
$2.45-3.44$ & 41 & 22.77 \\
$3.45-4.44$ & 135 & 75 \\
$4.45-5.00$ & 4 & 2.22 \\
Total & $\mathbf{1 8 0}$ & $\mathbf{1 0 0}$ \\
\hline
\end{tabular}

Source: Field Data, 2018 -2019

Interpretation:

$1.00-1.44$ Very Low (VL)

$1.45-2.44$ Low (L)

2.45 - 3.44 Moderate $(\mathrm{M})$

$3.45-4.44$ High $(\mathrm{H})$

$4.45-5.00$ Very High $(\mathrm{VH})$

Table 2 indicates that largest number of schools 135(75\%) had a high level of preparation as regards disaster management on food safety followed by $41(22.77 \%)$ who had moderate level of preparedness. 4(2.22\%) schools had a very high level of preparedness on food safety, everything had been put in place. In the aspects of adequate storage facility for food items, prohibition on illegal hawking or vending of food in school, food purchased for students, ensure food areas are clean, ensuring all food sellers in school have medical certificates, basic hygiene before and after meals and dietary needs of students.

To determine the contribution of principals to disaster management as regards to food safety a regression analyses were computed and the results were as shown in Table 3

Table 3: Contribution of Principals to Food Safety Model Summary

\begin{tabular}{lll}
\hline Aspects of Contribution & Adjusted R Square & Sig. F \\
\hline $\begin{array}{l}\text { Adequate storage facility for food } \\
\text { items }\end{array}$ & .244 & .000 \\
$\begin{array}{l}\text { Prohibition on illegal hawking or } \\
\text { vending of food in school }\end{array}$ & .066 & .000 \\
$\begin{array}{l}\text { Food purchased for students } \\
\text { Ensure food areas are clean }\end{array}$ & .497 & .000 \\
$\begin{array}{l}\text { Ensuring all food sellers in school } \\
\text { have medical certificates }\end{array}$ & .495 & .000 \\
$\begin{array}{l}\text { Basic hygiene before and after } \\
\text { meals }\end{array}$ & .349 & .000 \\
Dietary needs of students. & .348 & .000 \\
\hline
\end{tabular}

Table 3 indicates principals contributed to disaster management preparedness through ensuring adequate storage facilities are available. The contribution was $24.4 \%$ as signified by adjusted R square coefficient .244 . It can be noted that principals contribution to disaster management preparedness in terms of ensuring adequate storage facilities are significant indicators to disaster management preparedness. This model can be used to predict the influence of the factors (adequate storage facilities) on disaster management preparedness. Students' safety depends on how food is stored in school to protect them from falling sick. It 
also promotes cleanliness of all food items. Food poisoning in schools can cause death of students, principals should ensure they prevent food borne disease outbreaks.

Findings from the interview, CQASO said: "Safe storage of food will promote cleanliness of all food items and this will ensure there is no food poisoning in schools which can cause death of students". Schools are encouraged to ensure there's no hawking or vending in school to avoid diseases such as cholera and dysentery because food items from outside cannot be trusted. An Interview view by CQASO was this: "It's the principals duty to ensure the food is fresh, safe for students consumption, he needs to be sure of where the food has come from and how it's planted and where". This is very important for good health of the school community These findings agree with Republic of China (2011), which states more than 300 students at Changzhou City got food poisoning after lunch and it was established this was due to unsanitary conditions at school. Park, Kwak and Chang (2010), in their study on evaluation of food safety training for food handlers operations in Korea, 510 food borne disease outbreaks with 9,686 patients were reported with 93 of them being attributed to institutional food service on preparations. Food safety evaluation in Zaria, Nigeria using the Hazard Analysis Critical Control Plan (HACCP) system, found out that water for drinking and cooking was from dirty tap water environments, uncovered wells and boreholes Oranusi et, al (2007).

Republic of Kenya, (2008) states food safety is access and consumption of wholesome food that promotes good health and optimal body functioning. Ooro (2008) in his research has shown that, learners who have access to wholesome food have more enjoyable and successful learning experience. Knowledge and adequately trained foodservice staff can prevent food borne illness outbreaks originating in the cafeteria (FSP, 2005). Shaw (2002) in a study on international experiences and actions in promoting school safety states that new collections of exemplary, good or promising practices have been published. In literature such as the UNESCO (2007) and (ISDR) report (2008), Fothergill and Peek (2004), Paton and Johnston (2001) and Hosseini and lzadkhah (2006) there is strong evidence that the more prepared and knowledgeable a community is, the more resilient it becomes to disaster. Shaw et al., (2004), Hosseini and Izadkhah (2006) and Ozmen (2006) maintain that school education is important to ensure that learners respond appropriately when they are faced with a disastrous event.

Table 3 indicates principals contributed to food safety in preparedness to disaster management in terms of prohibition on illegal hawking or vending of food in school. The contribution was $6.6 \%$ of as signified by adjusted R square coefficient 0.066 . From Table 3 it can be noted that principals contribution to disaster management preparedness in terms of prohibition of illegal hawking or vending of food in school are significant indicators to disaster management preparedness. The school especially the principal has a legal and moral responsibility to ensure there's no illegal or vending of food to avoid diseases such as cholera and dysentery in school. Some of the food items brought in school from outside cannot be trusted, no one knows how and when they were prepared. Good health and nutrition are indispensable for effective learning. The findings agree with The South African National Curriculum Statements explicitly which prescribe the teaching of hazards and disaster learning outcomes in Grade 7 Social Sciences but are silent regarding this topic in lower grades and in other learning areas. An argument by Smith and Lovat (2003) that there is a hidden and explicit curriculum which imply that although not listed explicitly as learning outcomes, hazards and disasters can be regarded as hidden in other learning outcomes such as those related to the environment, water, forestation. No matter how much effort has been put into creating the perfect disaster plan, it will largely be ineffective if the staff and students are not aware of it, or if it cannot be 28 found during a disaster, (Patkus\& Walpole, 2007).

Dekens (2008) argue that indigenous and local knowledge, if combined

external, scientific knowledge, can enable implementing organizations to create innovative and sustainable solutions to reduce disaster risks and is important in building community confidence as communities themselves need to be convinced that some of their local knowledge and practices are relevant to disaster preparedness. According to a report by UNESCO (2007), education for disaster preparedness is a never-ending process that requires constant collaboration efforts by all parties concerned. Hartnady (2010) argues that sustainable development agencies must engage with education authorities to promote hazard awareness and community preparedness by influencing the development of new curricula, textbooks and teacher training in both primary and secondary schools.

World Food Program (2014) states a daily school meal provides a strong initiative to send children to school and keep them which allows them to focus on their studies rather than their stomachs. Lunch programs have favorable effects on educational attainment, Musamali (2008) regards school feeding program as one which improves school enrollment and attendance, academic performance and nutritional status of school children. Maritim (2014) in her study on school safety and emergency preparedness: an assessment of public boarding secondary schools in Nandi North District revealed that most schools were not adequately prepared for emergencies both in terms of planning and equipment.

Table 3 indicates principals contributed to food purchased for students in preparedness to disaster management. Principals contributed to disaster management preparedness in terms of food purchased for students. The contribution was $49.7 \%$ as signified by adjusted $\mathrm{R}$ square coefficient 0.401 . It can be noted that principals contribution to disaster management preparedness in terms of food purchased for students are significant indicators to disaster management preparedness. Good health facilitates enhances teaching and learning, student's health needs to be maintained and improved at all times through the food they are fed on. Foods brought in school should be checked by the Public 
Health Officers and they should have the rubber stamp of Kenya National Bureau of Standards to be sure of its value and expiry dates before consumption by the students. The school especially the principal has to ensure safety of food to avoid diseases such as cholera and dysentery in school. Some of the food items brought in school from outside cannot be trusted. Children focus on their studies rather than their stomach which is enhanced by a daily school meal World Food Program (2014).Lunch programs have favorable effects on educational attainment, Schools feeding program as one which improves school enrollment and attendance, academic performance and nutritional status of school children Musamali (2008). The school especially the principal has a legal and moral responsibility to ensure the school kitchen is kept clean through out to avoid diseases such as cholera and dysentery in school. Up to date information and materials on skills based on prevention of diseases in cooking areas should be availed to cooks. Education for disaster preparedness is a continuous process that requires constant collaboration efforts by all parties concerned, this is according to UNESCO (2007). Hartnady(2010) argues that sustainable development agencies need to work hand in hand with education authorities to promote hazard awareness and community preparedness by influencing the development of new curricula, textbooks and teacher training in both primary and secondary schools.

National governments, like in the USA because of fear of terrorist attacks they have changed their curricula to include learning outcomes on hazards and disasters King (2000). Ozmen (2006) and in Japan after the country had experienced a number of earthquakes (Shaw et al., 2004). A daily school meal provides a strong initiative to send children to school and keep them which allows them to focus on their studies rather than their stomachs (WHO, 2014). Lunch programs have favorable effects on educational attainment, Musamali (2008) regards school feeding program as one which improves school enrollment and attendance, academic performance and nutritional status of school children. Grant (2002) resonates that disaster awareness in schools, can be incorporated in institution through strategically posting safety rules, installing firefighting equipment, evacuation exits, maintain buildings, organizing seminars on disaster awareness and involving child-to-child peer education, the use of songs, electronic and print media, action learning and using science education as a means to introduce studies of disaster risk. Savula and Atsiaya, (2004) in their study established that, school managers should beef up security by employing adequate number of watchmen.(Republic of Kenya, 2001) includes guidelines

Table 3 indicates principals contributed to food safety in preparedness to disaster management. Principals contributed to disaster management preparedness in terms of basic hygiene before and after meals. The contribution was $34.9 \%$ as signified by adjusted $\mathrm{R}$ square coefficient .349 .

From Table 3 it can be noted that principals contribution to disaster management in terms of basic hygiene before and after meals are significant to disaster management preparedness. King (2000) observes that by raising awareness of expected hazards and increasing both knowledge of and active participation in appropriate preparations, it can be hoped that people will respond more effectively to warnings and behave safely when a disaster does occur. National governments have been seen to change their school curricula to include learning outcomes on hazards and disasters, like in the USA because of fears of terrorist attacks. Ozmen, (2006) and in Japan after the country had experienced a number of earthquakes (Shaw et al., 2004). Dekens (2008) that indigenous and local knowledge, if combined with external, scientific knowledge, can enable implementing organizations to create innovative and sustainable solutions to minimize disaster risks and is important in building community confidence as communities themselves need to be convinced that some of their local knowledge and practices are relevant to disaster preparedness. Musamali (2008) regards school feeding program as one which improves school enrollment and attendance, academic performance and nutritional status of school children. World Food Program (2014) states a daily school meal provides a strong initiative to send children to school and keep them which allows them to focus on their studies rather than their stomachs. Lunch programs have favorable effects on educational attainment. The findings revealed in terms of planning and equipment most schools were inadequately prepared. Principals contributed to disaster management preparedness in terms of dietary needs of students. The contribution was $34.8 \%$ as signified by adjusted $\mathrm{R}$ square coefficient .348 . It can be noted that principals contributions to disaster management preparedness in terms of dietary needs of students are significant indicators to disaster management preparedness.

Overally to establish the influence of principals contribution to food safety in enhancement of disaster management preparedness with regard to food safety regression analysis was computed using all the seven variables. Principals contributed to disaster management preparedness in terms of food safety. The contribution was 66.3 as signified by the adjusted $R$ square coefficient. 663 .

\section{Table 4: Multi Regression on Regression Analysis of food safety} Coefficients $^{\mathrm{a}}$

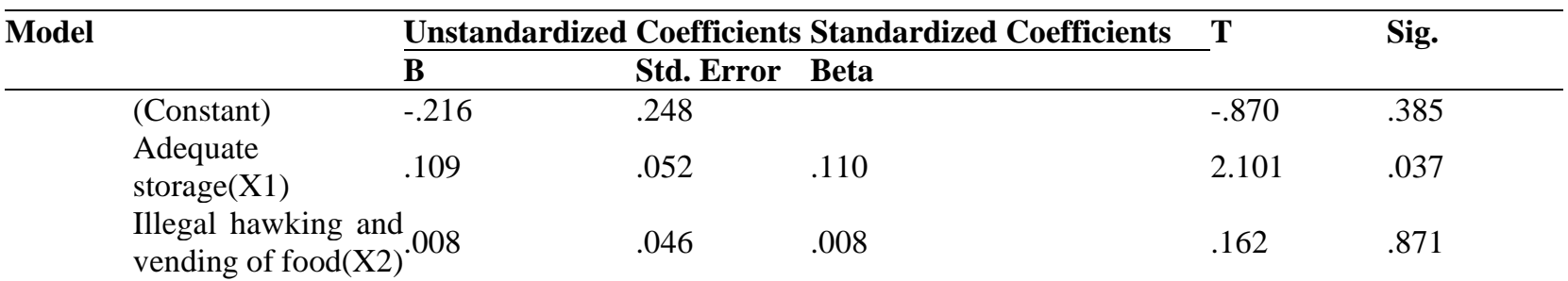




\begin{tabular}{|c|c|c|c|c|}
\hline $\begin{array}{l}\text { Food purchased for } \\
\text { students }(X 3)\end{array}$ & .036 & .253 & 4.443 & .000 \\
\hline $\begin{array}{l}\text { Areas where food is } \\
\text { prepared(X4) }\end{array}$ & .036 & .306 & 5.517 & .000 \\
\hline $\begin{array}{l}\text { Food sellers in }{ }_{.258} \\
\text { school(X5) }\end{array}$ & .028 & .412 & 9.163 & .000 \\
\hline $\begin{array}{l}\text { Basic hygiene } \\
\text { before and after(X6) }\end{array}$ & .035 & .101 & 2.045 & .042 \\
\hline $\begin{array}{l}\text { Dietary needs of } \\
\text { students(X7) }\end{array}$ & .034 & .215 & 4.540 & .000 \\
\hline
\end{tabular}

a. Dependent Variable: Disaster Management Preparedness

For every one unit increase in principals contribution to adequate storage facility for food items disaster management preparedness increases by .109 units

Adequate storage facility for food items helps in ensuring foodstuffs are stored well to avoid food poisoning. It also promotes cleanliness of all food items to avoid food borne disease outbreak.

With regards to prohibition of illegal hawking or vending of food in school, one unit increase in principals contribution enhances disaster management preparedness in schools by .008 units. In some schools there's no hawking or vending of food and in schools where it is allowed, it's done through supervision of teachers on duty and this is why principals are not doing much. As regards food purchased for students, for every one unit increase in principals contribution disaster preparedness is enhanced by .161 units. It involves ensuring that food purchased is in good condition, fresh and safe for consumption. These wards off cases of infectious diseases or ailments associated with low level of hygiene.

For every one unit increase in principals contribution to areas where food is prepared being clean disaster preparedness increases by .201 units. Places where food is prepared are cleaned every time and they remain clean always to encourage students safety when it comes to preparing food. As regards food sellers in school one unit increase in principals contribution enhances disaster management preparedness by .258 units. In terms of basic hygiene before and after meals for every one unit increase in principals contribution, disaster preparedness in enhanced by .071 units. Basic hygiene before and after meals is very important and has to be observed to avoid ailments associated with low level of hygiene. It will help keep students healthy and safe while in school. As regards dietary needs of students one unit increase in principals contribution it enhances disaster preparedness in schools by .154 units. Special needs of students in terms of diet needs to be taken into consideration because of different ailments they might be having. To help students remain health and safe in school principals need to work on the diet.

Overally the principals contributed $66.3 \%$ as earlier indicated. When regressed together there seem not much in prohibition on illegal hawking or vending of food in school, principals might not do much. The focus may be on the school canteen and no hawking or vending is allowed in school. The principal once sure of secure gates and security personnel he or she doesn't focus much on the issue. These findings agree with Republic of China (2011), which states more than 300 students at Changzhou City got food poisoning after lunch and it was established this was due to unsanitary conditions at school. Park,
Kwak and Chang (2010), in their study on evaluation of food safety training for food handlers operations in Korea, 510 food borne disease outbreaks with 9,686 patients were reported with 93 of them being attributed to institutional food service operations. Food safety evaluation in Zaria, Nigeria using the Hazard Analysis Critical Control Plan (HACCP) system, found out that water for drinking and cooking was from dirty tap water environments, uncovered wells and boreholes Oranusi et, al (2007).

Republic of Kenya, (2008) states food safety is access and consumption of wholesome food that promotes good health and optimal body functioning. Ooro (2008) in his research has shown that, learners who have access to wholesome food have more enjoyable and successful learning experience. Knowledge and adequately trained foodservice staff can prevent food borne illness outbreaks originating in the cafeteria (FSP, 2005). Shaw (2002) in a study on international experiences and actions in promoting school safety states that new collections of exemplary, good or promising practices have been published. Data has been collected and tools developed that support effective practice. Manuals, guides and training materials have been written. National, regional and international meetings have been organized by bodies such as the Council of Europe, the European Forum for Urban Security and the Australian Institute of Criminology to improve safety in schools. A number of countries have developed cross-sectional, national, regional or local strategies on implementing school safety. In literature such as the UNESCO (2007) and (ISDR) report (2008), Fothergill and Peek (2004), Paton and Johnston (2001) and Hosseini and lzadkhah (2006) there is strong evidence that the more prepared and knowledgeable a community is, the more resilient it becomes to disaster. Shaw et al., (2004), Hosseini and Izadkhah (2006) and Ozmen (2006) maintain that school education is important to ensure that learners respond appropriately when they are faced with a disastrous event.

\section{DISCUSSION}

Principals contribution accounted for $66.3 \%$ of disaster management as signified by 0.663 . Other factors were responsible for $33.7 \%$. Their contribution was found to be significant predictor of disaster management preparedness on school ground as shown 
by the $\mathrm{P}$ value less than 0.05 however, the contributions were found to have influence on school disaster management preparedness as revealed by regression analysis. The contribution considered storage, hawking, food purchased, food areas, food sellers, basic hygiene and special needs students. It was established that no principal contribution influenced preparedness of disaster management on its own as was signified by $r=0.244$, $\mathrm{P}<0.05$ for food items, $\mathrm{r}=0.066, \mathrm{P}<0.05$ for hawking, $\mathrm{r}=0.497$, $\mathrm{P}<0.05$ for food for students, $\mathrm{r}=0.741, \mathrm{P}<0.05$ for food areas, $\mathrm{r}=0.349, \mathrm{P}<0.05$ for basic hygiene, $\mathrm{r}=0.348, \mathrm{P}<0.05$ for dietary needs. That meant other percentages could be explained by other factors.

These findings agree with Republic of China (2011), which states more than 300 students at Changzhou City got food poisoning after lunch and it was established this was due to unsanitary conditions at school. Park, Kwak and Chang (2010), in their study on evaluation of food safety training for food handlers operations in Korea, 510 food borne disease outbreaks with 9,686 patients were reported with 93 of them being attributed to institutional food service on preparations. Food safety evaluation in Zaria, Nigeria using the Hazard Analysis Critical Control Plan (HACCP) system, found out that water for drinking and cooking was from dirty tap water environments, uncovered wells and boreholes Oranusi et, al (2007).

Republic of Kenya, (2008) states food safety is access and consumption of wholesome food that promotes good health and optimal body functioning. Ooro (2008) in his research has shown that, learners who have access to wholesome food have more enjoyable and successful learning experience. Knowledge and adequately trained foodservice staff can prevent food borne illness outbreaks originating in the cafeteria (FSP, 2005).

\section{CONCLUSION}

From the findings it was concluded that principals need to ensure food safety are secure for easy running of the school, to avoid court cases with neighbors who might claim ownership of the land, and to ensure all its activities are performed in school. Consequently food safety will be beneficial to the school and the whole community. It will also ensure safety for the students while in school.

\section{RECOMMENDATION}

Principals should make an effort in ensuring food safety for students based on adequate storage facility for food items, prohibition on illegal hawking or vending of food in school, food purchased for students, ensure food areas are clean, ensuring all food sellers in school have medical certificates, basic hygiene before and after meals and dietary needs of students.

\section{REFERENCES}

[1] Achoka, J.S.K. (2007). Kenya's Management of Secondary School Education in the 21st Century: New Model for excekebee. J-Stem.

[2] Adan, A.I. (2012). Factors Influencing Provision of Water and Sanitation in Primary Schools in Kaloleni Division, Kilifi District. Unpublished Masters Thesis, Maseno University.

[3] Adinku, S. (1999). Disaster Management in the Balme Library. Unpublished Thesis University of Ghana.
[4] Akali, N.M., Khabamba, I. \& Muyinga, G.A. (2013). Fire sources, disaster impacts and mitigation in Kenya Secondary Schools. [Online]. Retrieved from: International Journal of Disaster Management and Risk Reduction. 3(3). http://irpsonline.com. sg [2013, May 10].

[5] Akech, B.A.O. \& Simatwa, E.M.W. (2010). Opportunities and Challenges for head teachers of public primary schools in the implementation of Free Primary Education in Kisumu Municipality, Kenya: An analytical assessment. Retrieved on 3/11/017 at 8pm from http://www.academicjournals.org/ER2tringer.

[6] Alexander, D. (2002). Principles of Emergency Planning and Harpenden Terra Publishing: London.

[7] AMREF. (2005). Improving School Sanitation and Hygiene in Kenya. Net as Kenya: Nairobi.

[8] Anyuor, N. \& Weru, J. (May 2010 19th). Search for bodies of flood victims. Nairobi: Standard newspapers Ltd.

[9] Arson control forum, (2006). Surveys of School Fires, Research bulletin Number 10

[10] Ary, D. (2006). Introduction to Research in Education. Canada: Vicki Knight.

[11] Asian Disaster Preparedness Center (2008). A study on Impact of Disasters on the Education Sector in Cambodia, Bangkok: ADPC.

[12] Baltas, E. (2004). Safety of School Buildings in Greece, in OECD (2004), Lessons in Danger, International Conference on School Safety and Security, Paris, 12-14 November 2003.

[13] Blackaby, S. (2007). Fire safety education school [Online] Retrieved from http://www.esfrs.org/community_safety/Schools/schools.htm\#secondary[20 09, August 8].

[14] Brown, J. (1999). Doom, Quake and Mass Murder.dir.salon.com/topics.

[15] Burger, L. (2000). Background and Rationale to School Sanitation and Hygiene Education School Sanitation and Health Education. UNICEF, New York

[16] Calefati, J. (2009). School Safety 10 years after Columbine high school shooting. U.S. News and World Report

[17] Cavanagh, S. (2004). Schools abroad brace against terrorism. Education week, Nairobi.

[18] Chukwu, E.C. (2008). School safety and security: A Management challenge to principals in the Vryheid District. Published Master of philosophy thesis, University of Johannesburg.

[19] Cooper, M.A. (1995). Emergent Care of Lighting and Electrical Injuries. Seminars in Neurology Vol.15 No. 3: $268-278$.

[20] Dankit, K. Nassiuma (2017). An Introduction to Statistical Methods for Information Analysis. Utafiti Foundation, Eldoret.

[21] Denscombe, M. (2007). The Good Research Guide: For Small-Scale Social Research Projects. Berkshire: Open University Press.

[22] FAWE, (2001).Creating an Enabling Environment for Girls in School. The News Magazine about the Education of Girls and Women in Africa Vol.9 (1) January - March 2001. Nairobi: FAWE.

[23] Fire Administration National Fire Data Centre, (2007). Safety Issues, safety Articles, products, safety tips, safety issues, community and forums. www.safety issues.com accessed on 28th December, 2017 at $10.30 \mathrm{pm}$.

[24] Gaitho, M. (2001), July 30th). The Plight of Head teachers: Running Schools with little funds. Daily Nation Nairobi: Nation Media.

[25] Gicheru, C. (1998, March 28). These disasters can be averted. Daily Nation, Nairobi: Nation Media Group.

[26] Government of Kenya, (2008). Sector Plan for Environment, Water and Sanitation: 2008 -2012. Nairobi: Environment, Water and Sanitation Sector.

[27] Government of Kenya, (2009).National School Health and Policy. www.health.go.ke.Retrieved on 10/11/2017 at 9pm.

[28] Hirano, S. (2009). Child friendly Schools and Infrastructure. Rwanda Ministry of Education. Kigali.

[29] Hossein, I. \& Izadkhan (2006). Fire Safety Training: Its importance in enhancing Fire Safety Knowledge and Response to Fire. The Australian Journal of Emergency Management, Vol. 21 No.4

[30] Huck, S. (2000). Reading Statistics and Research. New York; Addison Wesley Longman. Inc.

[31] Ians, N. (2010). 1,200 Delhi Schools Lack Fire Safety Measures. Delhi: Ht Media Ltd International Finance Corporation (2010). Disaster and Emergency Preparedness. Guidance for Schools. Washington D.C. 
[32] INEE (2012). Inter Agency Network for Education in Emergencies. UN Plaza, New York. USA.

[33] ISDR (2002). Living with Risk: A Global Review of Disaster Reduction Initiatives. United Nations, Geneva, Switzerland, Karanja F.K, Mutua F.M, editors (2000). Reducing the impact of Environmental Emergencies through early warning and preparedness.

[34] ISDR (2010). Review of 8 MDGs' relevance for disaster risk reduction and vice - versa, http://www.unisdr.org/eng/mdgs-drr/review-8mdgs.htm.

[35] Karanja, F. \& Mutua, F.M. (2000). Reducing the impact of environmental emergencies through early warning and preparedness. www.unu.edu/env/govern/ElNino/Country Reports/pdf/kenya.pdf.

[36] Kasumba, M. (2004). How war on swamp fever was executed. East African Standard, Nairobi; The Standard Media Group.

[37] Keith, F. (2009). Introduction to Research Methods in Education. Thousand Oaks: Sage Publication. Kenya Red Cross S.

[38] Kenya Red Cross Society, (2000). Alleviating Human Suffering. Information Bulletin No. 2/2000; 1-20. Kenya Red Cross.

[39] Kombo, D.K. \& Tromp, D.L.A. (2006). Proposal and Thesis Writing: An Introduction. Nairobi: Paulines Publication Africa.

[40] Krathwohl, D. (2004). Methods of Education and Social Science Research: An Integrated Approach. Long Grove: Waveland.

[41] Lindonde, R. (2004). Sealing up school sanitation and hygiene promotion and gender concern, paper presented at the school sanitation and hygiene education symposium, June 8 -10, 2004.

[42] Lucheli, O. (2009). School Disaster Preparedness Poor. Nairobi Standard Digital.

[43] Lulua, L. (2004). Addressing School Safety in Uganda. Kampala: UPHOLDUSAID.

[44] Luvega, C.I. (2007). An Evaluation of Free Primary Education Policy in Selected Primary Schools in Kakamega District. Unpublished Masters Thesis. Maseno University.

[45] Makabila, S., Ayodo, H. \& Ringa, M. (2006). Putting out school fires. The Standard. Nairobi: Standard Media Group.P.5

[46] Makhanu, F.N. (2009). Disaster Preparedness as a Remedy to Fire Disasters in Learning Institutions of Kenya Centre for Disaster Management and Humanitarian Assistance. Unpublished Thesis, Masinde Muliro University of Science and Technology

[47] Mburu, M. (2012). Factors Influencing the Implementation of Safety Standards in Secondary Schools in Limuru District, Kiambu County, Kenya. Unpublished Masters Project: University of Nairobi.

[48] McNabb, C. (2009). Descriptive Research Methodologies. Retrieved on 2/10/2017 at $1 \mathrm{pm}$ from http://www.docstoc.com/docs/17400982/Descriptive-ResearchMethodologies.

[49] Maoulidi, M. (2005). Education needs assessment for Kisumu City, Kenya. Columbia Earth University: Millennium Cities Initiatives.

[50] Miles, B.M. \& Huberman, A.M. (1994). Qualitative Data Analysis. A Method Resource Book. College Press.

[51] MOE (2008). Safety and Standard Manual for Schools in Kenya (1st Edition). Nairobi; MoE Republic of Kenya.

[52] MOE, (2012). Nepal Education in Figures 2012 at a Glance. Ministry of Education, Government of Nepal: Kathmandu, Nepal. P. 23

[53] MOEST, (2011). A report of the task force on student discipline and unrest in secondary schools. Nairobi: Jomo Kenyatta Foundation.

[54] Mugenda, O.M. \& Mugenda, A.G. (2003). Research Methods: Quantitative and Qualitative Approaches. Nairobi: Acts Press.

[55] Muzaffargarh (2010). Pakistan: Flood Damaged Schools Lead to Education Worries www.Irinnews.org.

[56] NACADA (2002). Drug and Substance Abuse: The Kenyan Context. Nairobi: NACADA News.

[57] Nafula, N.N. (2002). Achieving Sustainable Universal Primary Education through Debt Relief. The Case of Kenya. Discussion Paper no. 2002/66, KIPPRA, Nairobi. KIPPRA.

[58] Nakitto, M. \& Lett, R. (2012). The Preparedness of Ugandan schools for fires. Makerere: Makerere Medical School.

[59] Nathe S.K. (2000). Public education for earthquake hazards. Natural Hazards Review, November; p. 191-196.
[60] National Centre for Education Statistics. (1995). "Student strategies to avoid harm at school" (Washington DC: US. Department of Education, October 1995), NCES 95-203.

[61] NCEF (2008). Earthquakes and Schools. U.S. Department of Education, Office of safe and Drug-free schools www.Ncef.or

[62] Nderitu, C. (2009). Implementation of Safety Standards Guidelines in Secondary Schools in Githunguri Division, Kiambu District. Unpublished Project, Kenyatta University.

[63] Ndirangu, L., Ocharo, M. \& Njoka, J. (2006).Vulnerability of Kenyan Schools to Disaster:

[64] A Case of Nairobi Public Secondary Schools, Unpublished M.Ed project,

[65] University of Nairobi.

[66] Ngecu, W.M., \& Mathu, E.M. (1999). The El-Nino- triggered landslides and their socio economic impact on Kenya. Environmental Geology 38:277-284.

[67] Odalo, B. (2001). Sixty eight dead. Daily Nation. Nairobi: Nation Media Group. Pp.1.

[68] Oduor, A. (2012).Tragedy Relieves Memory of Dormitory Deaths. [Online] Retrieved from Standard Digital News. Available at standardmedia.co.ke/?article ID=2000064691 \& page No. [2012, May 10].

[69] Okumu, M.A. (2014). Perceptions on Opportunities and Challenges for Public Secondary School Principals in the Implementation of Selected Safety Policy Guidelines in Kisumu West District, Kenya. Unpublished Thesis. Maseno University.

[70] Oranusi, et, al. (2007). Food Safety Evaluation in Boarding Schools in Zairia, Nigeria using the HACCP systems. Scientific Research Essay Vol.2 (10): 326-443.

[71] Oriang, L. (2001). Taking Charge of the welfare of our children. Daily Nation Nairobi: Nation Media Group.

[72] Otula, P.A. (2007). Mastery of Modern School Administration. Education Media: Nairobi.

[73] Orido, G. (2010). A different kind of theatre for action of a unique sort. www.standardmedia.co.ke.

[74] Orodho, J.A. (2003). Techniques of Writing Research Proposals and Report in Educational and Social Sciences. 1st ed. Nairobi: Masola Publishers.

[75] Ombati, C. (2012). Six Die in Dormitory Fire in Nairobi. [Online] Retrieved from Standard Digital News. Available at standardmedia.co.ke/?article $\mathrm{ID}=2000067677 \&$ story. title=six=die=in=dormitory=fire=in=Nairobi

[76] Omollo, O.D. (2011). An Assessment of the Implementation of Safety Policies in Public Secondary Schools in Kisumu West and East Districts. Unpublished Masters Thesis, Maseno University.

[77] Omolo, O. \& Simatwa, E.M.W. (2010). An Assessment of the Implementation of Safety Policies in Public Secondary Schools in Kisumu East and West District, Kenya Educational Research (ISSN: 2141-5161). Vol.1 (11).

[78] Onyango, M. (2008). Factors Influencing Participation Rates In Public Primary Schools In Rangwe Division of Homa-Bay District, Kenya. M. Ed project, University of Nairobi.

[79] Oriang' L (2001). Taking charge of the welfare of our children. Daily Nation, p. 5.

[80] Pandhal, S. (2005). Knowledge, Attitude and Practices of Oral Health Among Twelve Year Old Children Attending Urban Primary Schools in Kisuumu City. Unpublished Masters Thesis, Maseno University.

[81] Park,S., Kwak, T. \& Chang, H. (2010). Evaluation of Food safety training for food handlers in restaurant operations. The Korean Nutrition society and Korean Society of Community Nutrition. Downloaded 29th December, 2017

[82] Patkus, B.L. \& Walpole, M.A. (2007). Disaster Planning for Cultura Institutions. American Association for state and Local History. Nashville.

[83] Ramani, K. (2003, November, 29th). Education talks herald changes. East African Standard Nairobi: The Standard Media Group p.1.

[84] Ratemo, J. (2007, September 19). New Study claims Laboratory Assistants have died from Exposure to Harmful Chemicals. The Standard Nairobi; Standard Media Group.

[85] Redican, K., Olsen, L. \& Baffi, C. (1993). Organization of School Health Programs. Brown \& Benchmark, Madison.

[86] Reuters (2004). Indian School Fire Kills 90 Children. Retrieved on 24Th December, 2017 from http://www.wsws.org/articles/2017/ken-m30.shtml.

[87] Republic of Kenya, (2008). Safety Standard Manual for Schools in Kenya. Nairobi: S.R 54/2007.Government Printers 
[88] Republic of Kenya, (2001). Education Sector Reforms Action Plan 2001 2005. Policy Options, Nairobi: Government Printer

[89] Republic of Pakistan. (2003). Draft Guidelines for Education Sector ERWG. [Online].

[90] Retrieved from: http://floods2010.pakresponse.info/ [2018, Sept 27]

[91] Rocha,V. (2001). Ensuring Girls Safety in Schools. Retrieved on 28th December, 2017 at $11 \mathrm{pm}$ from www, girls' safety.org

[92] Roeder, W.P. (2003). Lighting Safety: It could Save your life. Observer The Magazine for Air force Weather, July - August 03, 32 - 33.

[93] Ronan, K.R. (1997). The effects of a "benign" disaster: symptoms of posttraumatic stress in children following a series of volcanic eruptions. Australas J Disaster Trauma Stud. [cited 2013 Jan 3]. Available from: http://trauma.massey.ac.nz/issues/1997-1/ronan1.htm.

[94] Ronan, K. et, al. (2010). Correlates of Hazards Education for youth: A replication study. Nat Hazards. 53:503-526. Doi: 10.1007/s11069-009-94446.

[95] Ronan, K.R. \& Johnston, D.M. (2001). Correlates of hazards education programs for youth. Risk Anal. 21:1055-1063.

[96] Ronan, K.R. \& Johnston, D.M. (2003). Hazards education for youth: a quasiexperimental investigation. Risk Anal. 23:1009-1020.

[97] Rowan, D. (2001). Kenya: School Fire Kills at Least 59 Students. Retrieved on 11th November, 2017 from http;//www.wsws.org/articles/ken-m30.shtml

[98] Sagara, R.K. (2012). Impact of Occupational Stress on Head Teachers' Tasks in Secondary Schools of Kisumu County, Kenya. Nairobi; Unpublished Master's Thesis Kenyatta University, Kenya.

[99] Savula, A. \& Atsiaya, P. (2004). Grilles order to school heads. The Standard p.4. Nairobi:

[100] Standard Group.

[101] Shaw, R. et, al. (2004). Linking experience, education, perception and earthquake preparedness. Disaster Prev Manage. 13(1):39-49.

[102] Shaw, M. (2002). Promoting Safety in schools: International experiences and actions. Crime prevention series No.3 Bureau of justice Assistance Monograph Washington, DC. United States Department of Justice.

[103] Shiwaku, K.et al. (2007). Future perspective of school disaster education in Nepal. Disaster Prev Manage. 16(4):576-587.

[104] Simatwa, E.M.W. (2007). Management of Student Discipline in Secondary schools in Bungoma District, Kenya." Unpublished Ph.D Thesis, Maseno University.

[105]Spencer, R.W. (2010). What causes Lighting National Weather Service. Office of Climate, Water and Weather Services Silver Spring.

[106]Teachernet, Fire Safety Area. (2007). Building Bulletin 100, Design for fire safety in schools. (http://www.teachernet.gov.uk/mngt/re).

[107]Toili, W.W. (2001). Impact of Environmental Education on Secondary School Students' Perspectives of Environmental Quality in Bungoma District. Unpublished PHD thesis, Maseno University.

[108]Tuckmaan B.W. (1994). Conducting Educational Research (5th ed.) Ohio State University. Harcourt Brace College Publishers.

[109] UNESCO, UNICEF. (2012). Disaster risk reduction in school curricula: case studies from thirty countries. United Nations Educational, Scientific and Cultural Organization and United Nations Children's Fund; Geneva, Switzerland. 208

[110]UNESCO (2007). Challenges of Implementing Free Primary Education in Kenya. Assessment Report. Nairobi: UNESCO
[111]UNICEF (2000).Global Water Supply and Sanitation Assessment Report. http;//www.who.int/doc.store/water/sanitation.healthGlobassesment/globa. Retrieved 30th December, 2017.

[112]UNICEF (2007). Kenyan School Children face Challenges LeftBy Recent Floods. UNICEF; Nairobi.

[113]UNISDR. (2004). Hyogo framework for action 2005-2015.United Nations Inter-Agency Secretariat of the International Strategy for Disaster Reduction; Geneva, Switzerland.

[114]UNISDR. (2007). Towards a culture of prevention: disaster risk reduction begins at school - good practices and lessons learned. United Nations International Strategy for Disaster Reduction; Geneva, Switzerland. p. 143.

[115] UNISDR. (2011). Compilation of national progress reports on the implementation of the hyogo framework for action. HFA Priority 3, Core Indicator 3.2; Geneva, Switzerland. Available from: http://www.preventionweb.net/english/hyogo/framework/progress/

[116]UNDP. (2008). National strategy for disaster risk management in Nepal. Kathmandu: MoHA, UNDP, EC, NSET; [cited 2012 Nov 13]. Available from: http://www.undp.org.np/pdf/NSDRMFinalDraft.pdf

[117]USDE, (2004).United States Education Department.

[118]USFDA (2008). Sanitation starts with physical facilities, US Public Health Service Food and Drug Administration.

[119]Veerashetcharappa, (2005). Community Contribution for Environmental Sanitation in the Rural Area Myth or Reality, India.

[120]Wachira et al (2011). Impact of Free Primary Education on Management of Schools in Embu District. International Journal of Business, Humanities and Technology Vol. 1 issue 2.

[121]Wedgwood, R. (2005). Post-Basic Education and Poverty in Tanzania. PostBasic Education and Training Working Pay: Series- No.1. Center of African Studies. University of Edinburgh.

[122]Wendo, B. (2002). Mudslides in Kenya. Nairobi: Daily Nation, April 16th $2002, \operatorname{pg} 8$

[123]WHO. (2009). Draft Wash Standards in Schools in Low-Cost Settings. http;//go.worldbank/org/OBRO8PH70/ retrieved on 28th December, 2017 at $11 \mathrm{pm}$.

[124]World Health Organization. (2005). Global Status Report on Road Safety: A Time for Action. Geneva: Switzerland: WHO.

\section{AUTHORS}

First Author - Pamela Ananda - Faculty of Education, Tom Mboya University.

Second Author - Prof. Enose M.W.Simatwa - Faculty of Education, Tom Mboya University.

Third Author - Dr. Stella Juma - Faculty of Education, Rongo University. 